\title{
Where Is the General Reference Librarian and Bread-and-Butter
}

\section{Service?}

\begin{abstract}
Research library growth and the increased emphasis upon graduate and professional training in universities has focused attention in recent years upon the need for subject specialists in public service areas of university libraries. Their advent has been helpful in raising the quality of scholarly service and in providing bibliographic and research service in greater depth than was previously possible. The general reference librarian, however, is still necessary-even in divisionally-planned buildings-to give library instruction, to answer basic reference queries from the less sophisticated patron, and to route more advanced users to the proper personnel for solution of their more profound library needs.
\end{abstract}

\section{W}

HAT IS HAPPENING to the general reference librarian? Is he slowly disappearing like the general practitioner in the field of medicine? In this age of specialization is there still need for the generalist in academic and large public libraries? The contention of this paper is that there is still a great need for the general reference librarian and that the library profession itself is to a degree responsible for his apparent obsolescence.

As knowledge proliferates, particularly in the areas of science and technology, no librarian is able to remain abreast of it. Subject specialist librarians are trying to keep up with the terminology, indexes, and abstracts in order to give intelligent directions to the patrons in the various disciplines. The general refer-

Mr. Hunt is Assistant Librarian and Head of Public Services at Oregon State University Library, Corvallis, Oregbn. ence librarian is also attempting to keep up, but the type of service that he can best provide is bread-and-butter service. This is not the deluxe service of the subject specialist, which may produce a definitive bibliography for a member of the faculty, but it is the staple, day-today service which should be available for all library users. This service needs to be reemphasized as libraries grow in size and complexity and as enrollments swell in the colleges and universities.

Bread-and-butter library service is the every day, every hour, every minute service that is made available at a public desk. It is the day-to-day contact with the patron, and it is convincing that patron that the librarian is there to help him interpret and use the resources and facilities of the library. Bread-and-butter service is a yeoman service that presents an ever-helping hand. This may sound trite and hackneyed, and perhaps it is. 
Nevertheless, it is basic to public services in the library. It is a combination of public relations, library instruction, and general reference.

Public relations is everyone's job in the library at all times, but it is carried on primarily through the direct personal contact between student and staff at the service desk. The word library means different things to many people. To some it represents the resources of the library. To others it may mean a place to study or to read the latest magazine or newspaper, or it may be a place to find a date for the Saturday night dance. But to many, the word library brings to mind the personal contacts they have made at the library and the service they have, or have not, received. Unfortunately, the patron usually remembers a rebuff far longer than he remembers good service. ${ }^{1}$

Library instruction is available at many levels and may range from how to locate a book on the shelf mechanically via the card catalog and call number to finding an uncataloged government document; from how to use the Readers' Guide or the New York Times Index to the use of the more difficult subject bibliographies. Students do need instruction in the use of the card catalog and indexes. While no one would refute Everett Moore's statement that these techniques "should be pretty well mastered before students come to college," 2 unfortunately it does not always happen. In fact, one could well wonder if some graduate students and faculty members have perhaps been accustomed to Mr. Rothstein's maximum service ${ }^{3}$ and as a result have difficulty in using some of the bibliographical sources on their own. Library instruction needs to be given at all bibliographic levels and be available for all

\footnotetext{
1 For a more detailed discussion of public relations, see: A. L. Kenny, "Public Relations in the College Library," CRL, XXV (July 1964), 263-66.

${ }^{2}$ Everett T. Moore, "Reference Service in Academic and Research Libraries," Library Trends, XII (January 1964), 362-72. Quotation from page 370 .

'Samuel Rothstein, "Reference Service: The New Dimension in Librarianship," $C R L$, XXII (January 1961), 11-18.
}

patrons regardless of their academic status. A dean may need as much help in the card catalog as a freshman. Perhaps the repetition of how to use the catalog, indexes, basic reference tools, etc., can be tiresome for the librarian, but it should not be. Library instruction is an essential and basic part of library service. It is part of bread-and-butter service, and it helps to establish the patron's confidence in himself and in the library.

Winning the confidence of the clientele at a reference desk is not something that happens automatically when some body is stationed at the desk to hand out reference books. It is something that has to be achieved through a constant, consistent effort. Once attained it does not necessarily remain, but it is the product of continued good reference service. One must be courteous and try to understand the confusion, bewilderment, aggressiveness, irritability, or whatever particular noun might be applicable, of the patron. Even if the answer to a question is not found, the patron will not be too disturbed if he believes the librarian was sympathetic with his problem and tried his best to solve it. If the patron receives perfunctory treatment, he will be reluctant to ask for help again. In showing a genuine desire to help, the librarian lays the foundation of the patron's confidence in the library and staff. ${ }^{4}$ This is part of bread-and-butter service. If the general reference librarian cannot answer the question, then the subject specialist can take over.

Consistent interest and enthusiasm are often hard to maintain. All librarians would prefer to aid the person who is capable of helping himself, who knows what he is after, and who needs only a suggestion or two to follow through on his own. All want to avoid the patron who is constantly lost, who refuses to help himself, and who is inclined to have

\footnotetext{
- For a discussion on establishing this confidence, see: Abraham Barnett, "The University Student and the Reference Librarian," CRL, XX (July 1959), 32124.
} 
a chip on his shoulder. These problem children are the ones to be won over. Most of these latter patrons have formed their attitudes through poor contacts at public service desks and to win their confidence should be a greater challenge than answering an esoteric reference question or compiling a thirty-page bibliography on cranberries.

Two of the seven items of the Rights of Library Users, based on the ACRL Standards for College Libraries, deal directly with these issues of assistance and instruction. The ACRL Committee on Library Services believed that the Standards were more for librarians and that some library users might not be aware of the service they were missing. The Committee was perhaps too kind to add that some librarians may not be aware of the service they should be offering. Points four and five of the Committee's preliminary draft are:

4. Assistance in its use. (Standards, IV). Help and advise in the use of the library, its materials, and its services should be available at all times from competent professional librarians. For faculty and research needs, this help should extend to literature searching, bibliography compilation, subject area guidance, and other specialized service as required.

5. Instruction in its use. (Standards, VII). Instruction in the use of the library should be integrated with or closely related to regular course work and should teach the organization of library resources and develop skill in the use of bibliographic and reference tools. The library staff may be expected to cooperate with the faculty in assuring that suitable training is offered. Both formal and informal instruction are desirable and should make use of such aids as a handbook or guide to the library's resources, facilities, and services; orientation tours, visual presentations; and individual consultations. ${ }^{5}$

The application of assistance and in-

s "Committee on Library Services," CRL, XXV (May 1964), 226, 228. The Standards can be referred to in: "Standards for College Libraries," CRL, $\mathrm{XX}$ (July 1959), 274-80. struction will vary greatly depending on the ability and academic level of the user. While a subject specialist may assume these responsibilities for the graduate students and faculty, the general reference librarian should provide these services to the underclassmen and the less-experienced library user.

Unfortunately, to some librarians, this bread-and-butter service of library instruction and library assistance or general reference, is dull, monotonous, and lacking in professional challenge. The more emphasis that is placed on librarians as subject specialists, the more impatient some seem to become with library instruction or with working at a general reference desk. The specialist in becoming more knowledgeable in his specific area may become less proficient in dealing with reference questions more general in nature and covering a wide range of disciplines and therefore may become less sympathetic with the problems of the new library user or the undergraduate. This is not an indictment against the subject specialist. $\mathrm{He}$ is the core of the divisional library and is essential for reference and bibliographic work in depth. It is rather a plea for recognition of the importance of breadand-butter service, a service not to the undergraduate alone, although he may be more directly concerned, but such a service to all library users. It is a suggestion that perhaps too much emphasis has been placed on divisional planning and that in the endeavor to give better service in depth, the equally important services of instruction, assistance, and reference in breadth, have suffered.

Many subject specialists, of course, do see the importance of bread-and-butter service and do not resent doing it along with their more scholarly endeavors, and some general reference librarians prefer more involved questions and believe that it is a waste of professional time to serve a desk where a large per cent of the questions are of the bread-and-butter 
variety. Some say that a well-trained nonprofessional or student clerk should sit at such a desk and cull these questions and refer the patron to a librarian when something of consequence arises. Disagreement, however, should be voiced with this philosophy of service. While it is true that a librarian on duty might refer the patron to another librarian more knowledgeable on the subject, or to a clerk who is competent to handle the problem, it is the decision of when to refer that is important. It is infinitely better that the librarian refer the patron to a well-trained clerk, than the reverse.

The decision of when to refer and to whom demands all the academic training and experience of the librarian and is as professional an act as any he will carry out at a public desk. This point of contact with the public is the culmination of all the work done behind the scenes. The library collection is selected, purchased, and arranged with one point in mind-to have the material available for use. The public service personnel are the connecting link between the resources of the library and the patron's use of these resources. The responsibility of the person at the desk is a great one, whether he is a subject specialist or a breadand-butter general reference librarian.

As previously stated, the general reference librarian and bread-and-butter service may be in danger of being administratively organized out of the public service pattern as a result of the emphasis during the last generation on the divisional plan and on subject specialists. What can be done to assure that bread-and-butter service will survive? First, clear recognition of the professional nature of general reference work must be reestablished. Second, the public service departments should be so organized as to afford a prime location for the bread-and-butter service. Third, enough personnel, and the right personnel, must be provided to offer this service during all hours the library is open.
Not all librarians want to work with the public, and not all public service librarians are suited by inclination or ability for general reference work. Many new professionals are looking for an adjective with their position classification. The title of humanities librarian, biological science librarian, fine arts librarian, etc., is much preferable in their eyes to just reference librarian. A library school graduate sometimes believes that his chances for advancement in the profession are much greater if he can identify himself as a special librarian, and in the larger colleges and universities he is often correct. The general reference librarian may be becoming a second class citizen.

Several generations ago when the forms and processes libraries were predominant with their closed stacks, circulation desk, and one main reference desk, the reference desk was the place the patron went for help. The general reference librarian was available at all hours the library was open. As libraries grew, however, and as the need for more subject reference service in depth developed, and as the open-stack philosophy took shape, the subject specialists at the divisional reference desks were able to provide reference service to a depth not so easily attained at a general reference desk. The divisional plan has proved its worth and has provided service to graduates and faculty that would have been difficult to achieve in the forms and processes library. However, two points must be observed. When three or six divisional desks replace a central reference desk, arrangements must be made to provide service to the undergraduate and to the patrons who do not need, nor know how to utilize, the help of a specialist. The other consideration is that a divisionalized plan of service demands more personnel. Some libraries have had a tendency to divisionalize beyond the available personnel, and as a result reference

(Continued on page 326 ) 
tion as most of them try to do now. Once persons are placed the library schools will continue to follow their graduates' progress closely and help them whenever possible to attain their professional potential. Placement officers will help place graduates of other library schools as well as their own whenever possible. The library schools' placement programs must make every effort to upgrade and refine but with the help of the library world in which they live.

\section{REFERENCE LIBRARIAN}

(Continued from page 310 )

service has become scattered and diluted.

Some divisions have been staffed with only one professional librarian, and as most academic libraries are open more than ninety hours a week, the specialist is available for less than half of the open hours. One might also ask, in what Mecca is there to be found a subject librarian who does not have also to be involved in administrative responsibility and in supervising such tasks as scheduling, amassing statistics, housekeeping of the area, filing reports, and so forth, and is only interrupted from his bibliographic pursuits by a faculty member or $\mathrm{PhD}$ candidate. The librarian cannot hope to spend the full forty hours he is at work rendering subject reference service. If one is fortunate to have welltrained career nonprofessionals available, they can substitute in his absence. Often student pages are filling in the gap.

The philosophies of library administration and organization that form the pattern of public services depend on too many local factors to allow analysis in detail. In general terms, the current divisional structure, if carried to extremes, risks completely supressing bread-andbutter service along with the general reference librarian. This important aspect of library service would be relegated to an information clerk sitting in splendid isolation by the umbrella stand giving traffic directions. Or it would fall by default to the clerks checking brief cases at the entrance or handling circulation work in the lobby. As Everett Moore has observed, the lack of a central reference service near the main card catalog leaves the patron in a state of confusion with nowhere to turn for assistance. Some libraries have established a token information center when the division plan of service removed the main reference desk and the situation became less than tolerable. Unfortunately, it is often impossible to reestablish a main reference desk when a building has been planned for divisionalized service. ${ }^{6}$

If the undergraduates are to receive good service and if bread-and-butter service is to survive, the general reference desk must be retained even in a divisional-oriented library. If possible, the desk should be in the proximity of the main card catalog, the first port of call, near the main entrance to the building. It should be more than an information and directional desk; it should have access to a general reference collection. In a completely divisionalized organization, the separate divisions often take on the aspects of separate libraries. Some college and university libraries are to all intent and purpose, four or five individual libraries in one building. There is need for one main desk which will not only handle informational and instructional problems, but which can deal as well with the reference needs of patrons who do not need the "in depth" help of the subject specialist; can refer the patron to the proper divisional desk; and can handle reference situations when the divisional desks are not manned. This main reference desk should be staffed at all times by professional librarians who are knowledgeable in all aspects of the profession and in the operations of their library, and they should be sympathetic toward bread-and-butter service.

- Moore, op. cit., p. 365 . 